\title{
Pemberdayaan Anggota Majelis Taklim Melalui Usaha Susu Kedelai Dan Nugget
}

\author{
Sutrisno \\ Universitas Islam Indonesia
}

Korespondensi: sutrisno@uii.ac.id

Diserahkan: 28 Juli 2018, Direvisi: 15 Agustus 2018, Diterima: 8 September 2018

\begin{abstract}
The purpose of community service is carried out on the members of the taklim assembly group (pengajian) in the Neighborhood Unit 62 of the Candi Gebang Permai housing complex, Sleman, Yogyakarta as a fostered partner, to empower the economy in order to increase household income. The activity carried out by cooperating with Omah Kedelai partners as the training material provider was by processing soy-based products in the form of soy milk and nuggets derived from soy milk dregs. The implementation method is in the form of training, and mentoring for entrepreneurship. At the end of the implementation of the program, the program worked well, as evidenced by the ability of foster partners to be able to produce and market soy-based products, so as to be able to group income at the same time can increase income for households.

Keywords: soy milk, nuggets, mothers of taklim assembly members, training, mentoring
\end{abstract}

abstrak

Tujuan pengabdian pada masyarakat yang dilakukan pada para ibu anggota kelompok majelis taklim (pengajian) di Rukun Warga (RW) 62 Perumahan Candi Gebang Permai, Sleman, Yogyakarta sebagai mitra binaan ini, adalah untuk pemberdayaan ekonomi dalam rangka menambah pendapatan rumah tangga. Kegiatan yang dilakukan dengan menggandeng mitra Omah Kedelai sebagai pemberi materi pelatihan, adalah dengan mengolah produk berbahan dasar kedelai berupa susu kedelai dan nugget yang berasal dari ampas susu kedelai. Metode pelaksanaan berupa pelatihan, dan pendampingan untuk berwirausaha. Pada akhir pelaksanaan kegiatan, program berhasil dengan baik, terbukti dengan kemampuan mitra binaan mampu memproduksi dan memasarkan produk berbahan dasar kedelai, sehingga mampu pendapatan kelompok sekaligus bisa menambah penghasilan bagi rumah tangga.

Kata kunci: susu kedelai, nugget, ibu anggota majelis taklim, pelatihan, pendampingan

\section{A. PENDAHULUAN}

\section{Latar Belakang}

Kelompok majelis taklim dengan anggota para ibu saat ini sudah menjadi trend diberbagai daerah dalam rangka menjalin silaturrahim sekaligus melakukan pengkajian ilmu-ilmu keagamaan dan kegiatan sosial. Pertemuan tersebut lebih banyak bertujuan sosial keagamaan dan belum menyentuh pada upaya peningkatan ekonomi produktif. Pertemuan rutin tersebut sebenarnya bisa dimanfaatkan menjadi peluang meningkatkan ekonomi keluarga dengan memberikan pelatihan untuk membuat produk tertentu yang teknik produksinya yang sederhana sehingga bisa dilaksanakan oleh anggota majelis taklim. Selain sebagai bentuk peningkatan kemampuan para ibu, kegiatan tersebut juga bias dikembangkan menjadi kegiatan wirausaha para ibu yang bisa menambah perekomian keluarga. 
Alasan pemilihan produk olahan berbahan dasar kedelai, adalah karena kedelai adalah bahan yang sangat mudah. Selain itu, banyak keunggulan yang terdapat pada kedelai antara lain mengandung protein, kalsium, fosfor, vitamin A, D dan vitamin B-1. Berdasarkan manfaat kedelai yang sangat luar biasa tersebut, maka tim pelaksana program kemitraan masyarakat (PKM) melakukan program pengabdian masyarakat berupa pemberdayaan para ibu anggota majelis taklim (pengajian) untuk usaha pengolahan susu kedelai dan nugget

\section{Profil Mitra}

Para ibu anggota kelompok Majelis Taklim yang ada di Rukun Warga (RW) 62 Perumahan Candi Gebang, Sleman Yogyakarata tidak jauh berbeda dengan kegiatan Majelis Taklim pada umumnya. Dalam seminggu, kelompok majelis Taklim ini melakukan pertemuan rutin bisa mencapai lebih dua kali. Kegiatan yang rutin dilakukan berupa membaca Al-Quran bersama semingu dua kali, kajian tafsir sekali seminggu, kajian umum seminggu, sehingga seminggu minimal empat kali pertemuan.

Tim pelaksana PKM melihat bahwa para anggota majelis taklim bisa diberdayakan untuk berwirausaha melalui kegiatan produksi barang berbahan dasar yang murah dan sederhana yaitu kedelai. Kegiatan ini melibatkan mitra pembina pelatihan yaitu Omah Kedelai, yang sudah berpengalama dalam kegiatan pengolahan susu kedelai dan nugget kedelai. Maka sesuai dengan keahlian yang dimiliki Omah Kedelai, mitra binaan diberikan pelatihan berupa pembuatan susu kedelai dan nugget dengan bahan dasar ampas kedelai.

\section{B. TINJAUAN PUSTAKA}

Kacang kedelaiterutama kedelai local, memiliki khasiat yang tinggi bagi kesehatan (Haliza, dkk, 2017). Kandungan gizinyapun lebih tinggi jika dibandingkan dengan susu sapi. Jika susu sapi rendah rendah lemak, demikian pula dengan kandungan susu kedelai. Dalam satu cup susu, masing-masing mempunyai kandungan 8 gram protein, sejumlah kalsium, fosfor, vitamin A, D dan vitamin B-1 (manfaat.co.id, 2018) Dengan banyaknya kadungan gizi pada kedelai, akan menambah produktivitas kerja (Ariati, 2013) Kandungan kalori dalam susu kedelai tidak sebanyak pada susu sapi, tetapi susu kedelai mempunyai kandungan asam lemak omega-3 yang baik untuk kesehatan jantung (Tumewa, 2018).

Ada 10 manfaat susu kedelai untuk kesehatan dan kecantikan, antara lai: 1) pembuluh darah semakin kuat dan menjaga stabilitas tekanan darah, 2) mengurangi obesitas, susu kedelai mempunyai kandungan protein tinggi dan asam lemak sehingga bisa meningkatkan keseimbangan gizi dan mengurangi kolesterol, 3) mencegah kanker prostat, 4) mengurangi sindrom post menopause, 5) mencegah osteoposis, 6) baik bagi penederita diates dan gangguan ginjal, 7) menjaga kesehatan jantung, 8) melindungi kerusakan kulit dari sinar ultra violet, 9) mencegah penuaan dini dan 10) mencegah terbetuknya jerawat. Begitu besarnya manfaat kedelai sehingga Wayuni et.al (2012) menyarankan kedelai untuk didiorong menjadi pangan fungsional di Indonesia. Mardalena (2017) juga menyebutkan gizi kedelai sangat baik bagi kesehatan manusia. Bahkan Miharja (2015) menyatakan kedelai bisa meningkatkan vitalitas pria. 


\section{METODE PELAKSANAAN}

Program pengabdian yang didanai oleh Direktorat Penelitian dan Pengabdian Masyarakat (DPPM) Universitas Islam Indonesia (UII) Yogyakarta ini bertujuan untuk memberdayakan ibu-ibu kelompok pengajian agar mampu menghasilkan tambahan penghasilan kelompoknya dan bagi keluarga. Usaha yang dikembangkan adalah pengolahan kedelai menjadi produk olahan kedelai. Target program ini adalah anggota kelompok pengajian mampu mengolah kedelai menjadi produk olahan berupa susu kedelai dan nugget serta memasarkannya.

Untuk mencapai target tersebut, ada beberapa metode yang akan digunakan agar peserta mampu mengolah kedelai menjadi produk olahan berupa susu kedelai dan nugget adalah pelatihan dan praktik produksi dan praktek bisnis. Berikut metode pelaksanaan yang dilakukan:

1. Observasi

Langkah awal sebelum pelaksanaan kegiatan adalah melakukan observasi dan wawancara terhadap ketua dan anggota kelompok pengajian, dalam rangka menggali motivasi dan kesungguhan masing-masing anggota kelompok. Dengan observasi bisa dipetakan minat masing-masing anggota dalam menglola usaha. Hasilnya didiskusikan dengan mitra kerja Omah Kedelai untuk merencanakan materi yang sesuai dengan kemampuan peserta pelatihan.

2. Pelatihan kewirausahaan.

Kelompok pengajian ini semula sebagai kelompok yang berorientasi sosial dan keagamaan dan akan diubah mindset-nya agar mempunyai visi bisnis. Untuk itu diperlukan pemberian wawasan berwirausaha dan memotivasi anggota organisasi. Dengan pelatihan ini diharapkan akan muncul semangat berwiraswasta. Tanpa adanya semangat dan jiwa wirausahawan, sulit sutau usaha bisa berhasil dengan baik.

3. Pelatihan produksi susu kedelai

Keahlian dalam membuat produk diperlukan dan kreativitas pengembangan produk juga sangat dibutuhkan sehingga setalah pelatihan tidak hanya bisa membuat produk tetapi bisa juga mengembangkannya. Pelatihan ini ditujukan untuk mengenalkan cara pembuatan produk susu kedelai. Pelatihan diberikan langsung oleh pendiri dan pemilik usaha omah kedelai. Masing-masing peserta dengan harus seksama memperhatikan proses produksi susu kedelai secara detail, sehingga masing-masing bisa saling meningatkan jika ada yang kelupaaan urutan prosesnya. Masing-masing peserta pelatihan juga langsung membantu proses pembuatan susu kedelai.

4. Praktikum produksi susu kedelai

Pendalaman dari pelatihan proses pembuatan susu kedelai dilakukan dengan praktikum langsung pembuatan susu kedelai. Semua proses produksi dilakukan oleh anggota paguyuban, sementara pelatih hanya mengamati dan memberi arahan jika ada alur proses yang salah. Juga melakukan evaluasi seberapa berhasil aktivitas praktikum yang telah dilakukan.

5. Pelatihan dan praktikum pembuatan nugget

Ampas kedelai setelah disaring biasanya hanya dibuang, digunakan untuk pakan binatang atau dibuat tempe gembus. Peserta diberi pelatihan untuk memberikan nilai 
tambah dari ampas tersebut manjadi nugget, dengan menambah dengan daging ayam atau sampi serta sayuran agar menjadi bergizi. Peserta juga langsung diberi kesempatan mempraktekan untuk menambah keahliannya.

6. Pelatihan pemasaran

Pelatihan pemasaran diberikan agar peserta mempunyai pengetahuan berbagai sarana untuk memasarkan produknya. Peserta diberi bekal berupa materi bauran pemasaran mulai bagaimana membuat produk (product) yang disukai konsumen, penentuan harga (price) termasuk menghitung harga pokok produksi yang nantinya digunakan sebagai dasar menentukan harga jual, bagaimana mempromosikannya (promotion) dan saluran distribusi (Kotler, 2008). Pemasaran yang diajarkan tidak hanya menjual langsung ke konsumen tetapi bagaimana membuat jaringan pemasaran agar produk yang dihasilkan semua laku terjual. Juga dilatih bagaimana menjual secara on-line. Dalam pelatihan pemasaran ini digunakan teknik role playing

7. Praktikum pemasaran

Praktikum pemasaran perlu dilakukan untuk menguji mental para peserta dalam menghadapi konsumen riil. Peserta diberi target untu bisa menjual sejumlah produk tertentu. Bagi yang mampu menjual paling banyak akan diberikan hadiah.

Produksi pembuatan susu kedelai maupun nugget sebenarnya cukup sederhana yang dengan mudah bisa dilakukan oleh peserta pelatihan. Peralatan produksi yang disediakan ada berbagai jenis yang secara lengkap seperti gambar 1, yang terdiri dari: 1) Mesin penggiling kedelai, 2) Panci dengan berbagai ukuran, 3) Alat perebus sari kedelai berbagai ukuran, 4) Kompor gas untuk merebus sari kedelai, 4) Lemari es sebagai penyimpan dan pengawet produk, 5) Generator set dimanfaatkan jika listrik mati, 6) Alat press kemasan, 7) peralatan kecil lainnya

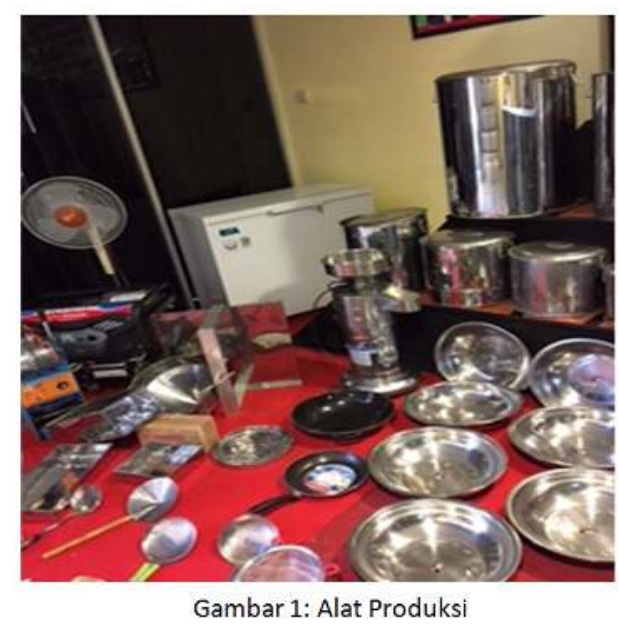

Proses produksi susu kedelai dan nugget tidaklah rumit. Berikut langkah-langkah pembuatan susu kedelai.

1. Perendaman, untuk memudahkan penggingan, maka kedelai harus direndam minimal 6 jam sebelum dilakukan penggilingan.

2. Penggilingan, dilakukan dengan memasukkan kedelai ke dalam mesin penggiling melalu corong sedikit demi sedikit. Hasilnya, air gilingan ditampung ke dalam panci yang sudah disediakan dan ampasnya dipanci lainnya. Jika kekedelai sudah habis digiling, ampasnya 
diberi sedikit air lalu digiling lagi dan berulang kira-kira tiga kali sampai sari kedelai relatif habis (gambar 3). Hasil akhir dari proses penggilinga ada dua sari kedelai yang siap diproses menjadi susu kedelai dan ampas yang selanjutnya diproses menjadi nugget.

3. Perebusan. Setelah proses penggilingan selesai, cairan air kedelai kemudian direbus selama kurang lebih satu jam. Kemudian diberi rasa dan pewarna jika diinginkan misalnya rasa strawberry atau rasa melon. Tujuannya agar supaya lebih disukai oleh para pembeli muda usia.

4. Pendinginan. Susu kedelai yang sudah direbus kemudian didinginkan agar memudahkan dalam pengemasannya.

5. Pengemasan. Setelah susu kedelai dingin langkah selanjutnya dikemas yang bertujuan untuk menarik konsumen. Jika dikemas dalam plastic biasa, maka harganya sangat murah. Dengan kemasan yang bagus akan lebih menarik dan bisa menaikkan harga jual. Susu kedelai dikemas ke dalam botol 1 liter dan diberi label sesuai dengan rasanya dan sementara ini label dari perusahaan pelatih Omah Dele

6. Penyimpanan. Setelah produk dikemas selanjutnya dimasukkan ke dalam lemari es untuk menjaga keawetan dan kualitas produk yang selanjutnya produk siap dijual kepada konsumen
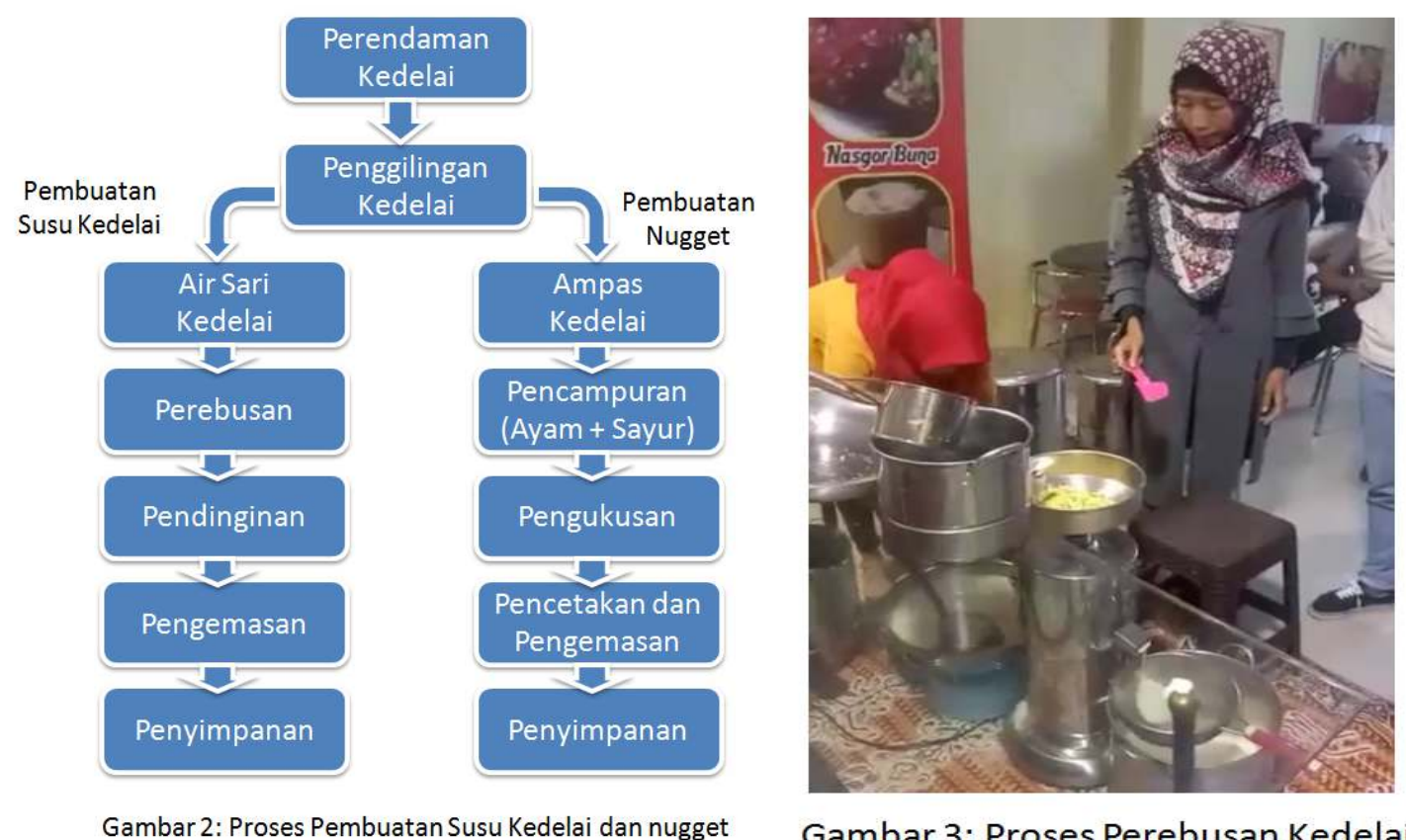

Gambar 3: Proses Perebusan Kedelai

Proses pembuatan nugget juga tidak rumit. Berikut langkah-langkah pembuatan nugget:

1. Pencampuran/pengolahan. Ampas dari hasil penggilingan bisa dimanfaatkan untuk membuat nugget. Ampas ini sebenarnya sudah tidak mempunyai kandungan gizi, untuk itu agar nugget yang dihasilkan mempunyai kandungan gizi yang tinggi, maka perlu dicampur dengan daging (daging ayam atau sampi) sesuai selera dan ditambah sayuran. Kemudian pengadukan dengan cara diblender dan di-mixer, sehingga menjadi adonan dan ditaruh pada loyang yang siap dikukus.

2. Pengukusan. Adonan yang telah dimasukkan dalam loyang kemudian dikukus hingga matang kurang lebih 1 jam, Setelah itu didinginkan untuk diporses selanjutnya. 
3. Pencetakan dan Pengemasan. Setelah adonan dingin kemudian dilakukan pencetakan sesuai dengan keinginan, bisa lonjong, bulat atau dalam bentuk lainnya yang menarik.
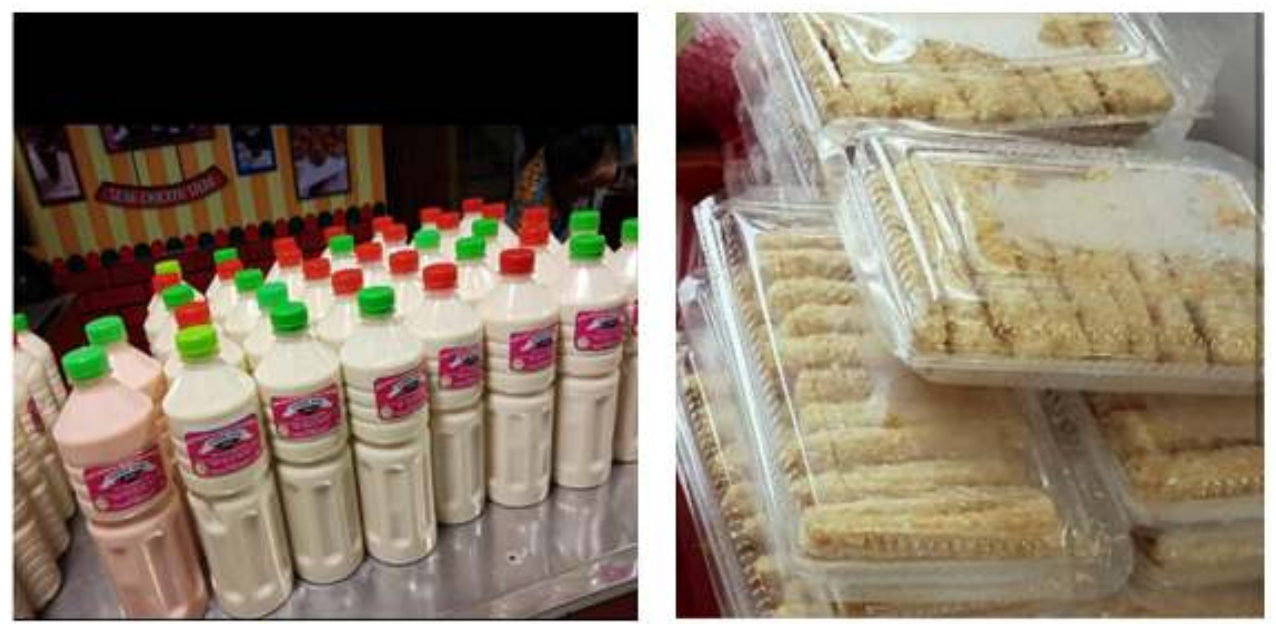

Gambar 4:

Hasil produksi susu kedelai dan nugget

\section{HASIL DAN PEMBAHASAN}

Pelatihan dan pendampingan yang dilakukan oleh tim PKM direspon sangat bagus oleh mitra binaan. Selain diberikan pelatihan untuk proses produksi, mitra binaan juga diberi pelatihan untuk menghitung aspek keuangan usaha. Pelatihan keuangan ini dibuat dengan metode yang sangat sederhana agar mudah dipahami peserta (Sutrino, 2016). Dari pengalaman Omah Dele jika usaha ini ditekuni, maka keuntungan yang diperoleh dengan hanya memproduksi $1 \mathrm{~kg}$ kedelai cukup besar, dengan perincian sebagai berikut:

\section{Estimasi Pengolahan 1 Kg Kedelai Susu Kedelai}

Harga $1 \mathrm{Kg}$ Kekedelai di tambah semua ramuan bumbu untuk dibuat susu kekedelai $\mathrm{Rp}$ 70.000

Menghasilkan susu kedelai 16 botol isi satu Liter

Harga per botol sekarang Rp 14.000,-

Penghasilan penjualan $=\mathrm{Rp} 14.000 \times 16=\quad \mathrm{Rp} 224.000$

Biaya

$\underline{\mathrm{Rp} 70.000}$

Laba dari susu kedelai (a)

$\mathrm{Rp} 154.000,-$

Nugget

Ampas dari gilingan kedellai dibuat Nugget bisa jadi 20 Pak isi 20 Biji

Harga Jual per pak Rp 12.000

Jadi total Penjualan nugget $20 \times \mathrm{Rp} 12.000,-=$

Rp 240.000,-

Pembuatan Nugget (beli daging ayam/sapi dan sayur) $\quad$ Rp 90.000,--

Laba dari nugget $(b)$

Total laba susu kedelai dan nugget $(\mathrm{a}+\mathrm{b})$

$\underline{\operatorname{Rp} 150.000,-}$

$\underline{\operatorname{Rp} 304.000,-}$

Program pengabdian masyarakat ini dilakasanakan selama satu bulan yang dimulai bulan Februari sampai Maret 2018, setiap sabtu atau minggu untuk memanfaatkan hari libur. Proses pengabdian diawali dengan survey dan wawancara dengan mitra binaan dan 
mitra usaha. Tujuannya untuk memetakan materi apa saja yang sebaiknya diberikan. Disepakti pelaksanaan program diawali dengan pemberian materi kewirausahaan kepada peserta dengan tujuan menumbuhkan jiwa wirausaha agar setelah pelatihan kelompok peserta ini bisa mengaplikasikan ilmu yang telah didapatkan untuk dijadikan sebagai sarana usaha.

Dari hasil pelatihan motivasi berwirausaha, nampak ada keseriusan ibu-ibu peserta dalam mengikuti pelatihan yang dibutktikan dengan banyaknya pertanyaan yang membuat suasa pelatihan hidup. Ada semangat dari peserta untuk dengan serius akan menjadikan kelompok pengajian ini tidak hanya kegiatan keagaan saja tetapi juga mengembangkan ekonominya. Peserta juga sangat antuisas mengikuti pelatihan pembuatan susu kedelai sehingga suasana menjadi sangat ramai dan penuh kegembiraan. Para peserta dengan tekun mengikuti semua proses produksi yang diajarkan oleh pelatih. Peserta juga selalu membantu pelatih dalam menyiapkan bahan, perlengkapan dan peralatan yang dibutuhkan. Para peserta dengan setia mengikuti seluruh rangkaian acara mulai proses awal sampai terkhir yakni pengemasan produk susu kedelai dan menyimpannya dalam almari es.

Selanjutnya, setelah proses produksi selesai dilanjutkan dengan memproses ampas kedelai menjadi nugget. Ini sangat istimewa karena biasanya ampas tersebut hanya dimanfaatkan untuk pakan ternak atau dijadikan tempe gembus yang tentunya tidak disukai oleh generasi muda serta kandungan gizinya sangat rendah. Tampaknya peserta sudah terbiasa dengan urusan masak memasak sehingga acara sangat lancar dan sukses. Proses dimulai dengan mencampurkan ampas kedelai dengan daging ayang dan sayuran untuk diblender dan dihaluskan, kemudian dikukus. Setelah itu didinginkan barulah dilakukan pencetakan dengan berbagai model.

Pada minggu berikutnya peserta diwajibkan mengikuti praktikum pembuatan susu kedelai dengan membawa bahan sendiri. Mitra kerja menyediakan tempat dan perlatanan dan peserta diminta melakukan proses produksi bersama kelompoknya. Pelatih hanya menlakukan pengawasan dan memberikaan arahan agar tidak ada kesalahan proses, namun nampaknya semangat ibu-ibu membuat suasana sangat ramai dan peserta sukses bisa membuat susu kedelai secara mandiri, karena memang prosesnya yang tidak terlalu sulit untuk dikerjakan. Praktikum pembuatan nugget juga sangat ramai karena memang peserta banyak yang mahir dalam soal masak memasak sehingga praktikum pembuatan nugget sangat lancar. Setelah praktikum, nugget yang sudah dibuat kemudian digoreng untuk dimakan bersama-sama. Dengan demikian pelatihan menjadi tidak membosankan.

Pemasaran menjadi faktor penentu bagi keberhasilan sebuah produk, karena itu pada minggu selanjutnya adalah pelatihan pemasaran. Pemateri tetap dari mitra kerja Omah Kedelai yang sudah berpengalaman memasarkan produk olahan kekedelai. Peserta diberi pelatihan bagaimana memasarkan produk susu kedelai dengan pasar sasaran yang tepat, dengan promosi murah mouth to mouth, memanfaatkan jaringan pengajian dan kelompok lainnya. Pada pemasaran jaman sekarang, juga harus mampu memanfaatkan media sosial baik melalui grup Watsapp, instagram, atau media sosial lainya. Juga diajari bagaimana memanfaatkan media on-line yang memungkinkan peserta pelatihan menjual produknya secara on-line, dengan mempertimbangkan masa kadaluarsa produk. Dalam pelatihan ini, selain Tanya jawab juga dilakukan role playing dimana ada peseerta yang ditunjuk 
berperan sebagai penjual dan sebagai pembeli, sehingga suasana menjadi sangat meriah karena melihat kelucuan penampilan peserta.

\section{E. PENUTUP}

Program pengabdian masyarakat dalam rangka memberdayakan kelompok pengajian ini berupa pembuatan produk susu kedelai dan inovasi produk nugget dari ampas kedelai. Program ini berjalan dengan baik, karena produk yang dihasilkan mudah untuk diproduksi. Tidak perlu memakan waktu yang lama untuk bisa menguasai tekonologi pembuatan susu kedelai ini, apalagi dilakukan oleh kelompok, sehingga lebih mempercepat penyerapannya. Pembuatan nugget dari ampaspun dengan mudah terserap oleh peserta, sehingga tinggal mengembangkannya terutama dalam rasa dan bentuknya.

Sampai saat ini masih ada komunikasi antara mitra binaan dengan Omah Dele karena jika ingin membuat susu kekedelai sendiri harus pinjam-sewa alatnya, hal ini karena harga alat realtif mahal. Sementara pangsa pasar terbuka lebar karena susu kedelai merupakan minuman sehat yang bisa dijual secara internal antar peserta pengajian, dan bisa dijual pada kelompok pengajian yang lain serta penghuni perumahan yang ekonominya rata-rata kelas menengah.

Memang masih ada kekurangannya yakni belum dimilikinya peralatan pembuatan susu kedelai, sehingga masih belum bisa mempraktekkan secara rutin baik pembuatan produk maupun pemasarannya. Untuk itu, direkomndasikan kepada para peserta untuk bisa patungan mengumpulkan dana dalam rangka membeli peralatan, karena sebenarnya secara ekonomi peserta mampu untuk menggalang dana, tinggal kemauan untuk maju. Selain itu, bagi pihak yang mau melaksanakan pengabdian masyarakat, bisa mereplikasi program pemberdayaan ini dengan peserta yang berbeda dan dengan menambahkan produk lain seperti tahu sehat.

\section{DAFTAR PUSTAKA}

Ariati, N.N,. 2013, Gizi dan Produkstivitas Kerja, Jurnal Skala Husada, Vol 10(2), 214-218 Haliza, W., Purwani, E.Y., dan Thahir, R, 2017, Pemanfaatan Kacang-Kacangan Lokal Sebagai Substitusi Bahan Baku Tempe Dan Tahu. Buletin Teknologi Pascapanen Pertanian Vol. 3

Miharja, F.J., Supriyanto dan Hariyadi, S,. 2015. Respon Pemberian Fitoestrogen dari Susu Kedelai (Glycine max (L) Merr) terhadap Kualitas Sperma Mencit Jantan (Mus-

Musculus) Strain Balb-C. Seminar Nasional XII Pendidikan Biologi FKIP UNS.

Kotler, P., 2008, Prinsip-prinsip Pemasaran, Ed 12, PT. Indek (Kelompok Gramedia), Jakarta Mardalena, Ida, 2017, Dasar-Dasar Ilmu Gizi, Pustaka Baru Press, Yogyakarta

Sutrisno, 2016, Manajemen Keuangan: Teori, Konsep dan Aplikasi, Penerbit Ekononis, Yogyakarta.

Tumewa-Bachrens, Inge., 2018, Eating Clean, PT. Kawanan Pustaka, Jakarta

Wahyuni, S,. Adawiyah, C.R dan Yofa, R.D,. 2012. Sosialisasi Kedelai sebagai Pangan Fungsional: Mendukung Program Intensifikasi Kedelai, Working Paper, Pusat Ekonomi dan Kebijakan Pertanian, Bogor. 209-220

www.khasiatsehat.com/khasiat-dan-manfaat-susu. Thursday 30th, August 2018 